\title{
Energy efficient thermochemical conversion of very wet biomass to biofuels by integration of steam drying, steam electrolysis and gasification
}

\section{Clausen, Lasse Røngaard}

Published in:

Energy

Link to article, DOI:

10.1016/j.energy.2017.02.132

Publication date:

2017

Document Version

Peer reviewed version

Link back to DTU Orbit

\section{Citation (APA):}

Clausen, L. R. (2017). Energy efficient thermochemical conversion of very wet biomass to biofuels by integration of steam drying, steam electrolysis and gasification. Energy, 125, 327-336.

https://doi.org/10.1016/j.energy.2017.02.132

\section{General rights}

Copyright and moral rights for the publications made accessible in the public portal are retained by the authors and/or other copyright owners and it is a condition of accessing publications that users recognise and abide by the legal requirements associated with these rights.

- Users may download and print one copy of any publication from the public portal for the purpose of private study or research.

- You may not further distribute the material or use it for any profit-making activity or commercial gain

- You may freely distribute the URL identifying the publication in the public portal 


\title{
Energy efficient thermochemical conversion of very wet biomass to biofuels by integration of steam drying, steam electrolysis and gasification
}

\author{
Lasse R. Clausen* \\ Section of Thermal Energy, Department of Mechanical Engineering, The Technical University of Denmark (DTU), \\ Nils Koppels Allé Bld. 403, DK-2800 Kgs. Lyngby, Denmark
}

Received: $x \mathbf{x}$

\begin{abstract}
A novel system concept is presented for the thermochemical conversion of very wet biomasses such as sewage sludge and manure. The system integrates steam drying, solid oxide electrolysis cells (SOEC) and gasification for the production of synthetic natural gas (SNG). The system is analyzed by thermodynamic modelling and the analysis shows that the system can handle mechanically dried biomasses with a water content of $70 \mathrm{wt} \%$ and an ash content of up to $50 \mathrm{wt} \%$ (dry basis). A high tolerable ash content is an advantage because very wet biomasses, such as sewage sludge and manure, have a high ash content. The analysis shows that the total efficiency of the novel system is $69-70 \%$ depending on the biomass ash content, while the biomass to SNG energy ratio is $165 \%$, which is near the theoretical maximum because electrolytic hydrogen is supplied to the synthesis gas. It is proposed to combine the novel system with an anaerobic digester for conversion of biomasses with high nitrogen content, such as sewage sludge. The organic nitrogen in the sewage sludge will be mineralized in the digester instead of ending up as $\mathrm{N}_{2}$ in the SNG product.
\end{abstract}

Keywords: steam drying, gasification, electrolysis, SOEC, synthetic natural gas, thermodynamic analysis.

\section{Introduction}

Very wet biomasses, such as sewage sludge and manure, are typically converted by anaerobic digestion to produce biogas. An issue with anaerobic digestion is however the low conversion efficiency, meaning that a significant amount of the chemical energy stored in the biomass is still available in the digested biomass. Thermochemical processes such as gasification can have a much higher conversion efficiency, leaving very little carbon in the gasification ash. To use very wet biomasses (water content above 70 wt\%) for gasification, a drying process is required. This drying process has a high energy demand and can therefore have high operational cost. However, if waste heat is available in the downstream processing of the biomass, the drying may not be a significant issue. This paper shows how very wet biomasses can be used for production of biofuels through gasification by using a steam dryer integrated with solid oxide electrolysis cells (SOEC). This novel concept is shown in Fig. 1 and can be compared with a more "conventional" system in Fig. 2. The novelty of the concept is the use of excess steam from the steam dryer in the SOEC, whereas the "conventional" system would have a separate boiler for raising steam to the SOEC. 


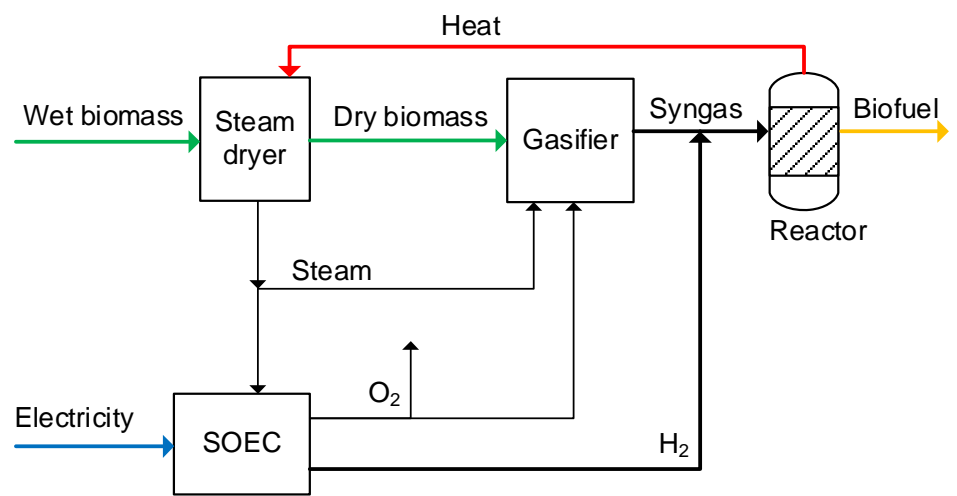

Fig. 1. Simplified flowsheet of the proposed system for utilization of wet biomass and electricity for biofuel production. Color description: green = biomass, blue = electricity, yellow = biofuel, red = heat.

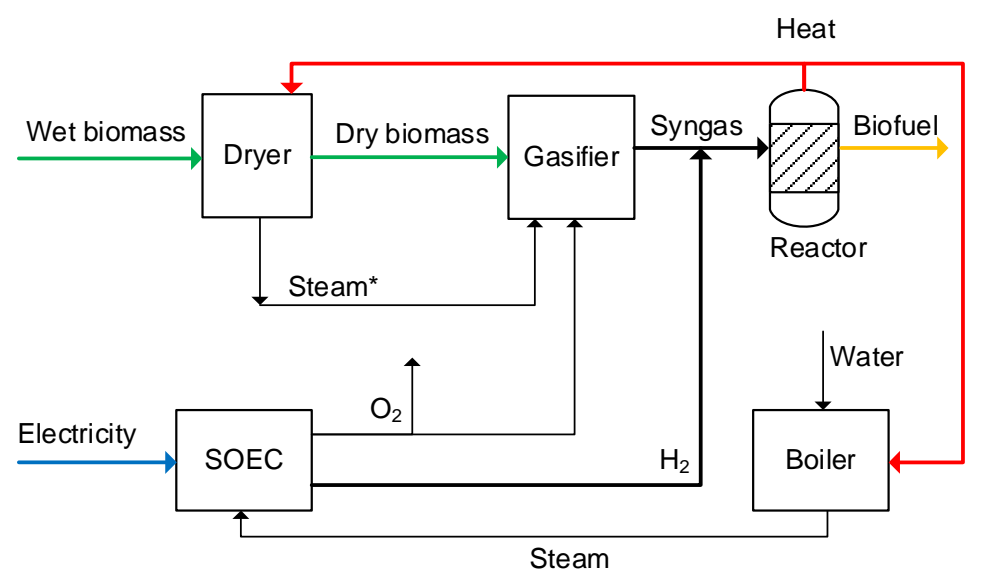

Fig. 2. Simplified flowsheet of a "conventional" system for integration of steam electrolysis and biomass gasification for biofuel production. *only if a steam dryer is used. Color description: green = biomass, blue = electricity, yellow $=$ biofuel, red $=$ heat.

In the novel concept, more waste heat will therefore be available for the steam dryer and the system can therefore tolerate biomasses with a much higher water content. Previous work within this field of integrating gasification and electrolysis for synthesis of fuels or chemicals include [1-8]. The biofuels produced in these references are: methanol [1,4-7], Fischer-Tropsch fuels [2], synthetic natural gas (SNG) [3], and dimethyl ether (DME) [8]. Liquid water electrolysis is used in these studies, except for $[2,8]$, in which steam electrolysis is used instead. None has considered using these systems for conversion of very wet biomasses, and none has considered supplying steam to the SOEC from a steam dryer. The use of wet biomasses for gasification has been studied before. In [9], gasification of dried sewage sludge is compared to pyrolysis of dried sewage sludge with subsequent gasification of the pyrolysis char. The energy demand of the drying and pyrolysis is found and compared with the available energy in the output gas and bio-oil. In [10], a process for bio-char production from sewage sludge is evaluated. In this study, the sewage sludge is first dried and pyrolyzed, and then some of the produced bio-char is gasified, and finally co-combusted with the volatiles from pyrolysis to cover the energy demand for pyrolysis and drying. Neither of these two references utilize waste heat for the drying of the wet biomass before gasification. In this paper, the novel system concept (Fig. 1) is analyzed by thermodynamic modelling and compared with the more "conventional" system (Fig. 2). Focus is on determining the maximum water content of the biomass that the system can tolerate, and show how this maximum depends on the biomass ash content, since these very wet biomasses can have a very high ash content. 


\section{Steam quality required by the SOEC}

The concept of using steam from a steam dryer in an SOEC has not been tested, and will only work if the steam is free of unwanted species. The unwanted species include particles, sulfur compounds, alkali compounds and halides [11]. The required cleaning could be limited to a bag house filter for particle removal, but if sulfur or alkali compounds or halides are released at these very low temperatures, which is considered unlikely, a guard bed would also be needed [11]. When drying biomass in steam at up to $200^{\circ} \mathrm{C}$, some organic compounds will be released according to [12]. In Fig. 3, the release of organic material vs. temperature is shown.

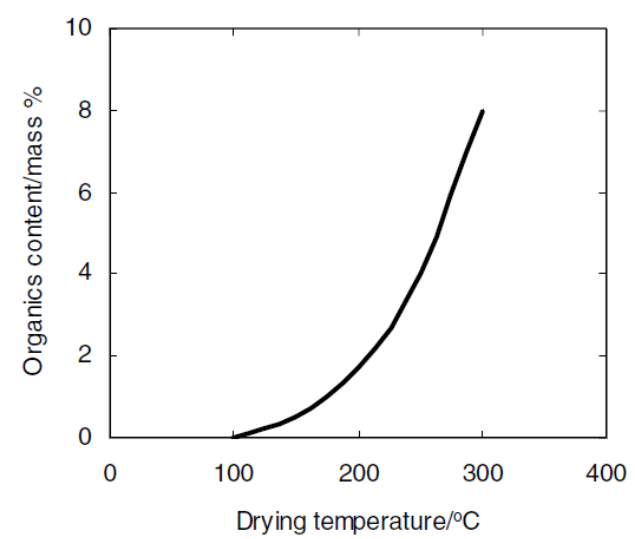

Fig. 3. Schematic dependence of total amount (wt\%, dry basis) of organic compounds released in atmospheric drying of biomass on temperature. From [12].

In the temperature range of approx. $100-150{ }^{\circ} \mathrm{C}$, acetic acid, formic acid, and formaldehyde are released, in the temperature range of approx. $150-230^{\circ} \mathrm{C}$, monoterpenes, fatty acids, and resin acids are released [12]. These compounds consists of $\mathrm{C}, \mathrm{H}, \mathrm{O}$ in various ratios. Because of the high temperature and the high catalytic activity of an SOEC, compounds consisting of $\mathrm{C}, \mathrm{H}$ and $\mathrm{O}$ are not considered a problem at very low concentrations as would be the case here [11]. In the unlikely situation that the compounds needs to be removed, an active carbon filter could be used [13].

\section{Choice of biofuel to produce}

The novel concept (Fig. 1) could, in principal, be used for production of many different types of biofuels, but the synthesis of methane for production of synthetic natural gas (SNG) is especially interesting because the methane synthesis is highly exothermic. This can be seen from eq. 1-4, where the methane synthesis reactions are shown together with the methanol synthesis reactions. The heat of reaction (change in standard enthalpy of formation) is given for each reaction. It can be seen that the methane synthesis releases more than double the amount of heat per converted $\mathrm{CO}$ or $\mathrm{CO}_{2}$ molecule compared with methanol synthesis.

Methane synthesis reactions:

$\mathrm{CO}+3 \mathrm{H}_{2} \leftrightarrow \mathrm{CH}_{4}+\mathrm{H}_{2} \mathrm{O}$

$\mathrm{CO}_{2}+4 \mathrm{H}_{2} \leftrightarrow \mathrm{CH}_{4}+2 \mathrm{H}_{2} \mathrm{O}$

Methanol synthesis reactions:

$\mathrm{CO}+2 \mathrm{H}_{2} \leftrightarrow \mathrm{CH}_{3} \mathrm{OH}$

$\mathrm{CO}_{2}+3 \mathrm{H}_{2} \leftrightarrow \mathrm{CH}_{3} \mathrm{OH}+\mathrm{H}_{2} \mathrm{O}$
$-206 \mathrm{~kJ}$

$-165 \mathrm{~kJ}$

$-50 \mathrm{~kJ}$ 
A higher heat release in the synthesis will mean that more waste heat is available for the biomass drying and the system will therefore be able to handle biomasses with higher water content. In the following calculations on the system, the produced biofuel is therefore SNG.

\section{Design of the biomass based SNG plant}

The designed system consists of four parts as seen on Fig. 1 and the more detailed Fig. 6; the steam drying, the gasification block, the solid oxide electrolysis (SOEC) block and the synthesis reactor block. Below, the modelling approach for each block is explained along with a section on the biomass feedstock used. The design parameters used in the thermodynamic modelling is given in Table 2. The system was modelled in the in-house modeling tool called DNA (Dynamic Network Analysis) $[14,15]$. DNA is a component based thermodynamic modelling and simulation tool that automatically includes conservation of mass and energy.

\section{Biomass feedstock}

The biomass feedstock used in the model is generic with a varying ash and water content. This is done to be able to represent many different biomass types, and to show how the maximum allowed water content depends on the ash content of the biomass. In Table 1, the composition of relevant biomass feedstocks are given to show that the ash content varies from about $1 \mathrm{wt} \%$ to $56 \mathrm{wt} \%$, but also to show the variations in ultimate analysis on a dry and ash free (daf) basis. Especially the nitrogen content varies significantly, from $0.2 \mathrm{wt} \%$ to $8.37 \mathrm{wt} \%$. The nitrogen content is of importance for SNG synthesis since most of the nitrogen ends up as $\mathrm{N}_{2}$ in the SNG product. The allowed nitrogen content in the produced SNG depends on the regulation of the specific country. For the modelling, the composition on dry and ash free basis is set equal to the composition given for "digestate from organic domestic waste" in Table 1. This is to show results for a biomass with a high nitrogen content that still complies with the natural gas regulations in Denmark ${ }^{1}$. In section 4.1, two alternative designs that can utilize biomasses with even higher nitrogen content are presented. Another way of mitigating the problem of nitrogen is to mix high $\mathrm{N}$ fuels with low $\mathrm{N}$ fuels such as wood.

Table 1

Composition of selected biomass feedstocks from the Phyllis2 database [16] [wt\%]

\begin{tabular}{|c|c|c|c|c|c|c|c|c|}
\hline & $\begin{array}{r}\text { Wood } \\
\text { chips }\end{array}$ & $\begin{array}{r}\text { Switch } \\
\text { grass }\end{array}$ & $\begin{array}{r}\text { Cow } \\
\text { manure }\end{array}$ & $\begin{array}{r}\text { Pig } \\
\text { manure }\end{array}$ & $\begin{array}{r}\text { Sewage } \\
\text { sludge }\end{array}$ & $\begin{array}{r}\text { Digested } \\
\text { sewage } \\
\text { sludge }\end{array}$ & $\begin{array}{r}\text { Digested } \\
\text { pig } \\
\text { manure }\end{array}$ & $\begin{array}{r}\text { Digestate from } \\
\text { organic domestic } \\
\text { waste }\end{array}$ \\
\hline $\begin{array}{l}\text { Moisture } \\
\text { content }\end{array}$ & $30-50^{a}$ & 12.64 & $70^{b}$ & 92.1 & $70^{c}$ & $70^{c}$ & $70^{c}$ & $70^{c}$ \\
\hline $\begin{array}{l}\text { Ash content } \\
\text { (dry) }\end{array}$ & 0.88 & 6.08 & 8.96 & $35.4^{d}$ & $42.3^{e}$ & $43.15^{\mathrm{e}}$ & $14.9^{d}$ & 56.1 \\
\hline C (daf) & $50.37^{f}$ & $49.88^{f}$ & 49.04 & $55.12^{f}$ & $52.76^{f}$ & 54.32 & $49.01^{f}$ & $48.66^{f}$ \\
\hline $\mathrm{H}$ (daf) & $6.04^{f}$ & $6.05^{f}$ & 6.43 & $6.90^{f}$ & $7.50^{f}$ & 7.67 & $6.16^{f}$ & $5.79^{f}$ \\
\hline$O$ (daf) & $43.35^{f}$ & $43.37^{f}$ & 41.94 & $33.58^{f}$ & $30.66^{f}$ & 27.46 & $41.86^{f}$ & $41.36^{f}$ \\
\hline$N$ (daf) & $0.20^{f}$ & $0.58^{f}$ & 2.25 & $4.40^{f}$ & $7.07^{f}$ & 8.37 & $2.45^{f}$ & $2.98^{f}$ \\
\hline$S$ (daf) & $0.04^{f}$ & $0.12^{f}$ & 0.34 & - & $2.01^{f}$ & 2.18 & $0.53^{f}$ & $1.20^{f}$ \\
\hline $\begin{array}{l}\mathrm{C} / \mathrm{N} \\
\text { [mole frac] }\end{array}$ & 293 & 100 & 25 & 15 & 9 & 8 & 23 & 19 \\
\hline $\begin{array}{l}\text { LHV (daf) } \\
{[\mathrm{MJ} / \mathrm{kg}]}\end{array}$ & 18.41 & 17.84 & 18.60 & 19.86 & 21.87 & 21.91 & 19.53 & 19.47 \\
\hline $\begin{array}{l}\text { ID-number in } \\
\text { database }\end{array}$ & $-g$ & $-h$ & 2782 & 1366 & $-i$ & 2913 & 2903 & 2907 \\
\hline
\end{tabular}

daf $=$ dry and ash free.

1 The gas regulations in Denmark are stricter than in Germany. In Denmark, the Wobbe Index must be higher than 50.76 $\mathrm{MJ} / \mathrm{Nm}^{3}$ (HHV) and the relative density must be higher than 0.555 [27]. 
a the reported moisture content was after drying. A typical moisture content is given instead (30-50 wt\%).

${ }^{\mathrm{b}}$ mechanically dried to $70 \mathrm{wt} \%$

${ }^{c}$ the reported moisture contents were after drying. These biomasses are very wet but could be mechanically dried to 70 wt $\%$

(see footnote b).

${ }^{d}$ the ash content of pig manure varies. It was expected that the ash content reported for digested pig manure was greater than that for raw pig manure.

e the ash content of sewage sludge varies. It was expected that the ash content reported for digested sewage sludge was greater than that for raw sewage sludge.

${ }^{f}$ normalized (sum $\left.=100\right)$.

g 22 samples of mixed hardwood chips exists in the database. The median values are reported.

h 49 samples exists in the database. The median values are reported.

i 43 samples exists in the database. The median values are reported.

\section{Steam drying}

The steam dryer dries the wet biomass from the received water content to a water content of $10 \mathrm{wt} \%$. A lower water content could be achieved, but since biomasses other than wood chips may need to be pelletized after drying, the palletization sets the achievable water content before gasification. A water content of $10 \mathrm{wt} \%$ would be realistic for biomass pellets.

The surplus steam generated by the steam dryer is split into three mass flows; one goes to the SOEC, one goes to the gasifier and one is vented or condensed. The heat required by the steam dryer is waste heat from the downstream methane synthesis reactor.

\section{Gasification block}

The Two-stage gasifier is used for the conversion of biomass to clean syngas. The advantages of the Two-stage gasifier is high cold gas efficiency and very low tar content in the produced syngas [17]. The disadvantage of the Two-stage gasifier is the limited potential to be upscaled. It is estimated that the gasifier could be scaled up to a maximum of 3-10 MWth biomass input $[18,19]$. Changes in the design of the gasifier could lead to feasible large-scale concepts. The gasifier was designed to operate on wood chips, but recent tests shows that it can also operate on sludge pellets with a high ash content. The gasifier has so far only been air-blown, but it should be possible to make it oxygen-blown by mixing the oxygen with sufficient steam. The "Viking" gasifier pilot plant is currently being converted to oxygenblown operation in this way. The oxygen content of the oxygen-steam mixture is in the modelling 10-14 vol\%. The cold gas efficiency of the gasifier is $89-93 \%$ depending on the ash content. On wood chips, the cold gas efficiency has been measured to be $93 \%$ [17]. The gas composition is calculated by assuming that the water gas shift reaction is in equilibrium at $750^{\circ} \mathrm{C}$, which matches measurement on the gasifier reported in [17]. The methane content is higher than predicted by chemical equilibrium and is instead set according to the measurements reported in [17]. The gas from the gasifier is cleaned for particles by a bag house filter at $\sim 90^{\circ} \mathrm{C}$ (above dew point) before leaving the gasifier block. Measurements have shown that the sulfur content after the bag house filter is very low when operating on wood chips (approx. 2 ppm). A sulfur guard will however be needed before the synthesis reactor downstream. Certain high-sulfur biomasses could result in too high sulfur loads on the sulfur guard resulting in the need for a dedicated sulfur removal step before the synthesis reactor.

\section{SOEC block}

Solid oxide electrolysis cells (SOEC) are used for conversion of electricity and steam to hydrogen and oxygen. Solid oxide electrolysis cells are essentially the same as solid oxide fuel cells (SOFC), but they are operated in reverse mode, e.g. producing fuel from electricity (SOEC) instead of producing electricity from fuel (SOFC). The SOEC technology has been demonstrated in several demonstration plants, the biggest being a $120 \mathrm{kWe}$ SOEC supplied by Sunfire to Boing [20]. This SOEC can also operate as a SOFC producing $50 \mathrm{kWe}$. The steam for the SOEC is supplied by the biomass steam dryer. The produced 
hydrogen is mixed with the gas from the gasifier to generate a syngas with a module $M=3$ (eq. 5), which is optimal for methane synthesis (eq. 1-2). A part of the produced oxygen is used by the gasifier. In the modelling, the SOEC cells are operated above the thermoneutral voltage at $800^{\circ} \mathrm{C}$, which is $1.29 \mathrm{~V}$, but in practice the SOEC cells may operate below thermoneutral voltage, as recent measured data suggests [21], and then be supplemented by electrical heaters (heating the steam before the SOEC). The SOEC can have an electricity to hydrogen efficiency of more than $100 \%$ (LHV) when operated below the thermoneutral cell voltage, but this requires a high temperature heat input to the SOEC [22]. If the high temperature heat input is generated by electric heaters, then the SOEC will, in theory, have an electricity to hydrogen efficiency of $100 \%$ (LHV) when operated below or at the thermoneutral cell voltage. The reason why a real SOEC system will have a lower electricity to hydrogen efficiency than $100 \%$ is because of various losses (heat loss, inverter loss) and auxiliary power consumptions (blowers, etc.) $[22,23]$, but also because the outlet hydrogen from the SOEC is typically used to heat up the input steam, which means that the hydrogen temperature must be higher than the steam temperature at both inlet and outlet of the hydrogen-steam heat exchanger. The concept described in this paper dictates the use of steam from the steam dryer, so liquid water electrolyzers are not relevant for this concept.

$$
M=\frac{\mathrm{H}_{2}-\mathrm{CO}_{2}}{\mathrm{CO}+\mathrm{CO}_{2}}
$$

\section{Synthesis reactor block}

The syngas is compressed to $7 \mathrm{bar}$ and then led to a cooled methane reactor. The product gas from the reactor is cooled to ambient temperature to condense out water, and is then heated before being fed to an adiabatic methane reactor in order to increase the methane content. Hereafter water is removed again, first by condensation and then by glycol or a solid adsorbent. The heat from the cooled methane reactor, and the main part of the heat released in the following product gas cooling, is supplied to the biomass steam dryer. The product gas from both reactors is assumed to be in chemical equilibrium at the outlet temperature and pressure. This assumption has been shown to be in agreement with measured data on a methane reactor [24].

Table 2

Process design parameters used in the modeling.

\begin{tabular}{|c|c|}
\hline Feedstock & $\begin{array}{l}\text { Biomass with varying water and ash content. The dry and ash free composition (daf) is assumed to } \\
\text { be (wt\%): } 48.66 \% \mathrm{C}, 5.79 \% \mathrm{H}, 41.36 \% \mathrm{O}, 2.98 \% \mathrm{~N}, 1.2 \% \mathrm{~S}, \mathrm{LHV}=19.47 \mathrm{MJ} / \mathrm{kg}_{\text {daf }} \cdot \mathrm{C}_{\mathrm{p}}=1.35 \\
\mathrm{~kJ} /\left(\mathrm{kg} \mathrm{dry}^{*} \mathrm{~K}\right) \text {. The biomass input is } 5.0 \mathrm{MWth} \text { (LHV dry). }\end{array}$ \\
\hline Steam dryer & $\mathrm{T}_{\text {exit }}=110^{\circ} \mathrm{C} . \mathrm{T}_{\text {superheat }}=200^{\circ} \mathrm{C}$. Dry biomass moisture content $=10 \mathrm{wt} \%$. Pressure loss $=0.03 \mathrm{bar}$ \\
\hline Steam blower & $\eta_{\text {isentropic }}=50 \%, \eta_{\text {mechanical }}=97 \% . \eta_{\text {electrical }}=97 \%$. \\
\hline Gasifier & $\begin{array}{l}\mathrm{P}=1 \text { bar. Carbon conversion }=99 \% \text { [17]. Heat loss }=3 \% \text { of the biomass thermal input (LHV dry). Texit } \\
=730^{\circ} \mathrm{C}[17] . \text { The gas }\left(\mathrm{excl} . \mathrm{CH}_{4}\right) \text { is assumed to be in chemical equilibrium at } 750^{\circ} \mathrm{C}[17] . \\
\mathrm{CH}_{4} /\left(\mathrm{CO}+\mathrm{CO}_{2}+\mathrm{CH} 4\right)=3.2 \text { mole } \% \text { [17]. Pyrolysis is modelled by assuming a } \mathrm{c}_{\mathrm{p}}=1.85 \mathrm{~kJ} /\left(\mathrm{kg}{ }^{*} \mathrm{~K}\right) \text { for } \\
\text { bone dry and ash free biomass }{ }^{\mathrm{a}}[19] . \mathrm{c}_{\mathrm{p}} \text { of ash }=1 \mathrm{~kJ} /\left(\mathrm{kg}{ }^{*} \mathrm{~K}\right) \text {. Pressure loss }=0.03 \text { bar. Total } \\
\text { water } / \text { steam input mass flow is set equal to the mass flow of dry and ash free biomass }(0.257 \mathrm{~kg} / \mathrm{s}) \text {. }\end{array}$ \\
\hline SOEC & $\begin{array}{l}\text { Inlet temperature }=770^{\circ} \mathrm{C} \text {. Exit temperature }=800^{\circ} \mathrm{C}[21]^{\mathrm{b}} \text {. losses }=5 \% \text { of input electricityc } 10 \% \mathrm{H}_{2} \\
\text { in feed steam [21]. } 20 \% \text { steam in outlet } \mathrm{H}_{2} \text {. These data result in a total energy efficiency from } \\
\text { electricity to hydrogen of } 92 \% \text { (LHV). }\end{array}$ \\
\hline Syngas compressor & $\eta_{\text {polytropic }}=80 \%, \eta_{\text {mechanical }}=97 \% . \eta_{\text {electrical }}=97 \%$. Intercooled to $95^{\circ} \mathrm{C}$ (above dew point) at 2.6 bar. \\
\hline SNG synthesis & $\begin{array}{l}\text { Boiling water reactor followed by an adiabatic reactor. Chemical equilibrium at reactor outlet } \\
\text { temperature and pressure [24]. Reactor outlet temperature of boiling water reactor: } 300^{\circ} \mathrm{C} \text {. } \\
\text { Reactor pressure: } 7 \text { bar. }\end{array}$ \\
\hline Heat exchangers & $\begin{array}{l}30^{\circ} \mathrm{C} \text { (gas-gas), } \Delta \mathrm{T}_{\min }=10^{\circ} \mathrm{C} \text { (gas-liq or gas - condens. gas). In pyrolysis stage: } \Delta \mathrm{T}_{\min }=100^{\circ} \mathrm{C} \text { (gas- } \\
\text { solid). }\end{array}$ \\
\hline
\end{tabular}


Note: the results can be reproduced by using the data presented in this table.

a the heat for pyrolysis is then calculated by $\mathrm{C}_{\mathrm{p}} * \Delta \mathrm{T}=1.85 \mathrm{~kJ} /(\mathrm{kg} * \mathrm{~K}) *\left(630^{\circ} \mathrm{C}-110^{\circ} \mathrm{C}\right)=962 \mathrm{~kJ} / \mathrm{kg}_{\text {daf }}$

${ }^{\mathrm{b}} \mathrm{A}$ temperature increase of $30^{\circ} \mathrm{C}$ results in an energy efficiency (excl. losses) from electricity to hydrogen of $97 \%$ (LHV). If the SOEC stack is not capable of having a temperature increase of $30^{\circ} \mathrm{C}$, then it could be operated in thermoneutral mode at $800^{\circ} \mathrm{C}$ and an electrical heater would preheat the steam input from $770^{\circ} \mathrm{C}$ to $800^{\circ} \mathrm{C}$. This would result in the same overall electricity to hydrogen efficiency.

c the losses include: 1 . heat losses (2\%), 2. inverter losses and electricity consumption of blowers and other auxiliary components (3\%) [23].

d The methanation catalysts from Haldor Topsøe can operate in a temperature span of $220^{\circ} \mathrm{C}$ to above $700^{\circ} \mathrm{C}$ [25]. The outlet temperature is not set to $220^{\circ} \mathrm{C}$ because this temperature is only used as the inlet temperature for an adiabatic reactor. It should be noted that if the boiling water reactor had been an adiabatic reactor the outlet temperature would not exceed $700^{\circ} \mathrm{C}$ because of the high steam and $\mathrm{CO}_{2}$ content in the syngas. This is important because the gas temperature will increase rapidly after the inlet to the boiling water reactor and thereafter decrease slowly towards the exit temperature of $300^{\circ} \mathrm{C}$.

\section{Results}

The main results of the simulations are collected in Fig. 4 and Fig. 5. Fig. 4 shows the maximum water content of the wet biomass that the novel system can handle and compares it with the "conventional" system (Fig. 2). Fig. 5 shows the same information, but in the form of kg water per kg biomass (dry or daf). Fig. 4 is useful because the water content that can be obtained by mechanical drying (e.g. centrifuge) is around $70 \mathrm{wt} \%$, while Fig. 5 better shows how much water the systems really can tolerate and the comparison with the conventional system is also clearer. The figure shows that the maximum amount of water (kg water) per kg of organic matter (biomass daf) is almost constant. This is as expected. The results show that the novel system can handle $82-84 \%$ more water than the conventional system. Assuming a water content of $70 \mathrm{wt} \%$, the results show that the novel system can handle biomasses with $50 \mathrm{wt} \%$ ash, while the conventional system can handle $10 \mathrm{wt} \%$ ash. Because biomasses with a water content of $70 \mathrm{wt} \%$ or more, typically have a high ash content, the novel system has a clear advantage compared with the conventional system.

Detailed results of the modelling is shown in a flowsheet (Fig. 6) and Table 3 for a biomass ash content of $50 \mathrm{wt} \%$ (dry) and at the maximum water content (71 wt\%). Fig. 6 shows that with the assumed steam input to the gasifier, there is still a significant surplus of steam generated by the steam dryer (stream no. 12). This excess steam corresponds to $38 \%$ of the steam generated by the steam dryer. This steam could be condensed and the heat used for district heating. Fig. 6 also shows that only a fraction (15\%) of the oxygen generated by the SOEC is used by the gasifier, the rest (85\%) is vented. If the required heat by the steam dryer (3.0 MWth) is compared with the thermal input of biomass ( $5.0 \mathrm{MWth}$, dry basis) it can be seen that this corresponds to $60 \%$. This clearly shows that the system is very dependent on the SOEC to provide hydrogen for the methane synthesis in order to boost the methane production, and thereby boost the heat generation in the methane synthesis.

In Table 4, important energy efficiencies are given, and it is shown how these efficiencies vary with biomass ash content. Table 4, shows that the total efficiency of the system (biomass + electricity to SNG) is $69-70 \%$ depending on the ash content of the biomass (1-50 wt\%). This corresponds to a total chemical exergy efficiency of $70-71 \%^{2}$. A high ash content lowers the cold gas efficiency of the gasifier and therefore the total efficiency is slightly reduced. A decrease in cold gas efficiency results in a decrease in the $\mathrm{CO} / \mathrm{CO}_{2}$ ratio in the gas from the gasifier, which leads to an increase of the required electrolyzer hydrogen output and hence power consumption (Table 4).

\footnotetext{
${ }^{2}$ The calculation of the chemical exergy efficiency is done in the conventional way as described in e.g. [28]. In detail this means: 1 ) for the biomass input the higher heating value (HHV) is used (5.3 MWth), 2) for the electricity input energy = exergy (6.8-7.0 MW), 3) for the SNG output the exergy is calculated as described in [28] for a gas mixture (8.6 MWth) - this includes using the standard chemical exergy of each gas compound which is supplied in [28].
} 


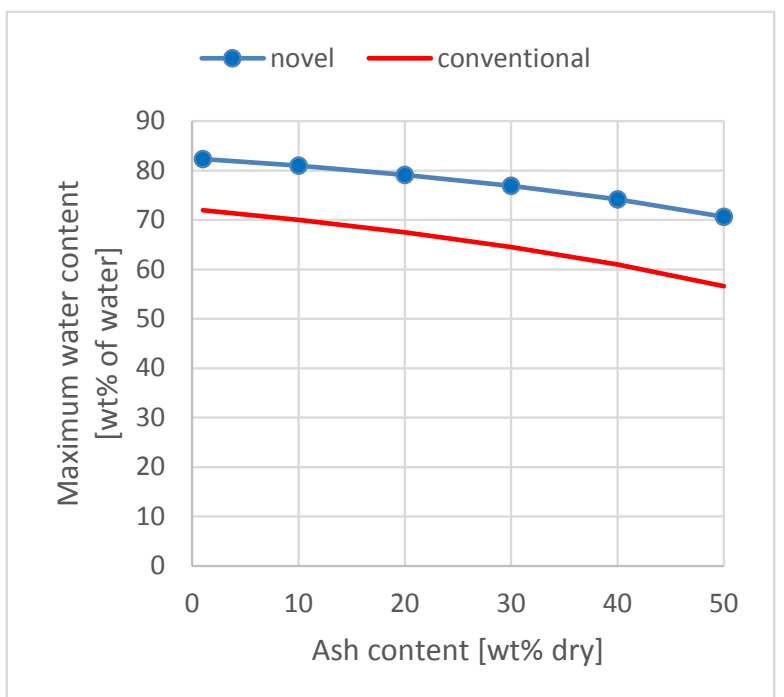

Fig. 4. Maximum water content in biomass vs. biomass ash content for both the novel and the conventional system.

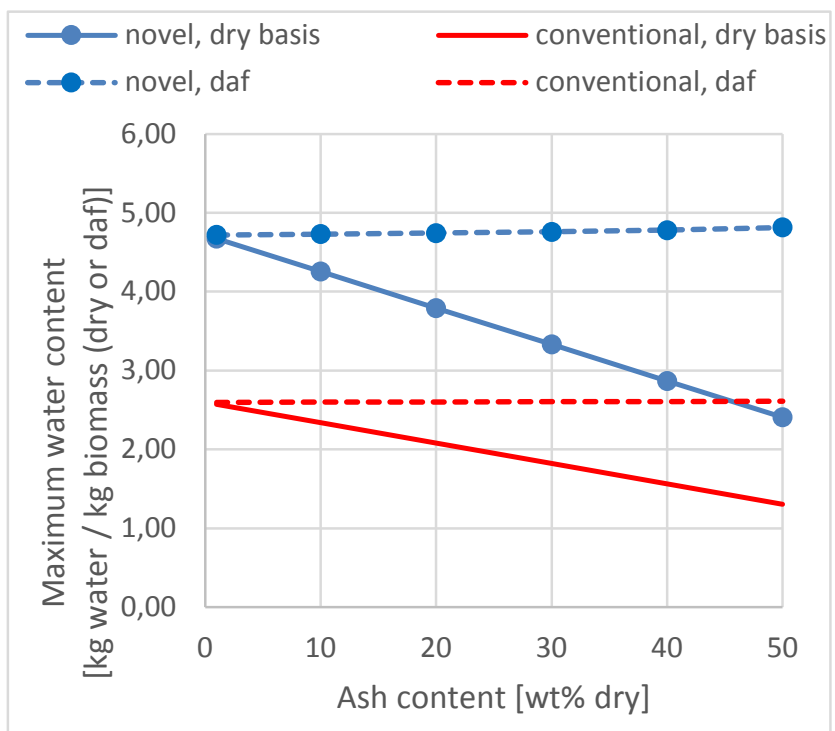

Fig. 5. Maximum water content in biomass vs. biomass ash content for both the novel and the conventional system. 


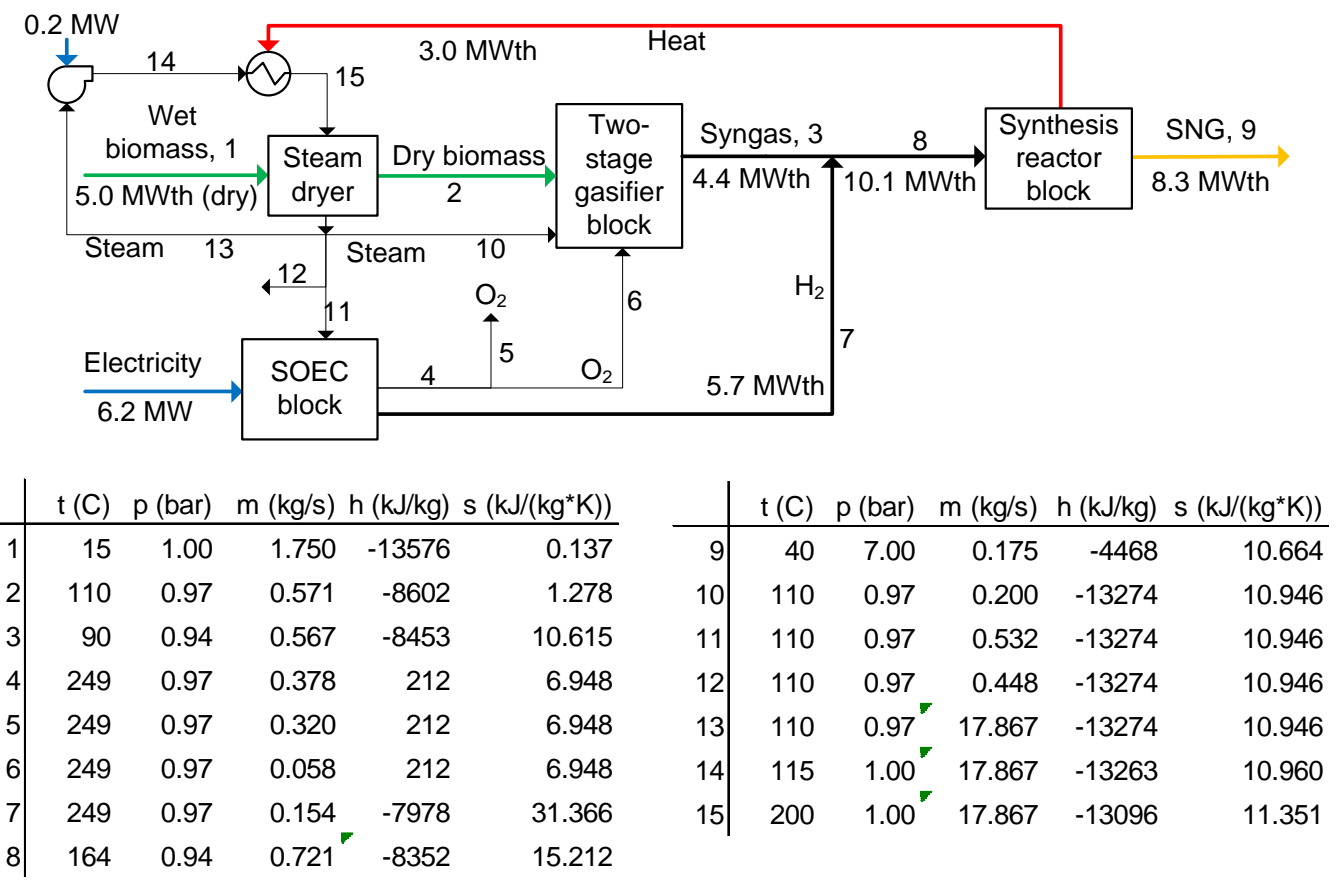

Fig. 6. Detailed flowsheet of the novel system for utilizing wet biomass and electricity for synthetic natural gas (SNG) production. The flowsheets of the three individual blocks (gasifier, SOEC and synthesis reactor) can be found in appendix. Color description: green = biomass, blue = electricity, yellow $=$ biofuel, red $=$ heat .

\section{Table 3}

Stream compositions (stream numbers refer to Fig. 6 unless stated otherwise)

\begin{tabular}{lllll}
\hline & $\begin{array}{l}\text { Gasifier } \\
\text { exit }\end{array}$ & $\begin{array}{l}\text { Reactor } \\
\text { inlet }\end{array}$ & $\begin{array}{l}\text { Reactor } \\
\text { outlet }\end{array}$ & SNG \\
\hline Stream number & 3 & 8 & 4 , Fig. 11 & 9 \\
\hline Mass flow (kg/s) & 0.567 & 0.721 & 0.721 & 0.175 \\
Flow (mole/s) & 31.4 & 60.9 & 41.6 & 10.8 \\
\hline Mole\% & & & & \\
$\mathrm{H}_{2}$ & 36.4 & 57.5 & 3.0 & 1.7 \\
$\mathrm{CO}$ & 15.3 & 7.9 & $\sim 0$ & $\sim 0^{\mathrm{a}}$ \\
$\mathrm{CO}_{2}$ & 16.4 & 8.5 & 0.8 & 0.4 \\
$\mathrm{H}_{2} \mathrm{O}$ & 29.9 & 25.1 & 71.6 & 0.0 \\
$\mathrm{CH}_{4}$ & 1.0 & 0.5 & 24.0 & 95.3 \\
$\mathrm{~N}_{2}$ & 0.9 & 0.4 & 0.7 & 2.5 \\
\hline sum & 100.0 & 100.0 & 100.0 & 100.0 \\
\hline a $33 \mathrm{ppm}$ & & & &
\end{tabular}


Table 4

Summary of energy inputs and energy efficiencies.

\begin{tabular}{lrr}
\hline Biomass input [MWth] & & 5.0 \\
\hline Electricity consumption: & [MWe] & [\% of biomass \\
input] \\
Electrolysis & $6.0^{\mathrm{b}}-6.2^{\mathrm{a}}$ & $120^{\mathrm{b}}-124^{\mathrm{a}}$ \\
Steam blower & 0.2 & 4 \\
Syngas compressor & 0.6 & 11 \\
Total electricity consumption & $6.8^{\mathrm{b}}-7.0^{\mathrm{a}}$ & $135^{\mathrm{b}}-140^{\mathrm{a}}$ \\
\hline Energy ratios and efficiencies [\%]: & & \\
Biomass to syngas & & $89^{\mathrm{a}}-93^{\mathrm{b}}$ \\
(cold gas efficiency) & 82 \\
Syngas (incl. $\mathrm{H}_{2}$ ) to SNG & & 165 \\
Biomass to SNG & & $119^{\mathrm{b}}-122^{\mathrm{a}}$ \\
Electricity to SNG & & $69^{\mathrm{a}}-70^{\mathrm{b}}$ \\
Biomass + electricity to SNG & & \\
(total efficiency) & & \\
\hline SNG: & & 0.563 \\
\hline Wobbe index [MJ/Nm ${ }^{3}$ ] (HHV) & & \\
Relative density & & \\
\hline
\end{tabular}

note: each parameters dependence on biomass ash content is given, if no interval is given, then the parameter does not depend on the biomass ash content. ${ }^{a}$ biomass ash content of $50 \mathrm{wt} \%$ (dry), b biomass ash content of $1 \mathrm{wt} \%$ (dry),

c Wobbe index $=\frac{H H V\left[\frac{M J}{N M^{3}}\right]}{\sqrt{d}}$, by assuming ideal gas, the specific gravity $d$ is calculated as: $d=\frac{\text { density of gas }}{\text { density of air }}=\frac{\text { molar mass of gas }}{\text { molar mass of air }}$.

\section{Discussion}

The novel system concept has shown that it is possible to convert very wet biomasses to SNG with an energy efficiency equal to that, which is possible for conversion of dry biomasses. It is however possible to increase the conversion efficiency a little bit more, but this is at the expense of the maximum water content of the biomass. This is discussed below. The system concept could also be integrated with a biogas plant or an external carbon feed for the combined upgrading to SNG, this is discussed in section 4.1.

Tradeoff between maximum water content and energy efficiency

There is a tradeoff between maximum water content and energy efficiency. This is because that condensing out water before the syngas compression will lower the compression work and thereby increase the total efficiency, however the heat released by condensing the steam after the methane reactor will be decreased - therefore lowering the maximum water content of the biomass. For a biomass with $50 \mathrm{wt} \%$ ash (dry), the total energy efficiency is increased from $69 \%$ to $70 \%$, while the maximum water content is reduced from $70 \mathrm{wt} \%$ to $65 \mathrm{wt} \%$ (this is a reduction of $24 \%$ in the amount of water per biomass input). However, removing steam before the methane reactor increases the adiabatic equilibrium temperature of the methane synthesis, which means that the temperature in the first part of the methane reactor could become too high. A recycle of the product gas from the reactor could therefore be needed. Removing water before the syngas compression will also result in higher methane content in the final product, therefore also higher wobbe index, so the maximum allowed nitrogen content of the biomass would also increase.

This tradeoff between maximum water content and energy efficiency also applies to the conventional system (Fig. 2), so the difference in maximum water content between the two systems would be constant. 


\subsection{Combining the proposed system with a biogas reactor or an external carbon feed}

Although this novel system concept would compete with an anaerobic digester for wet biomass, there are some advantages in combining the two technologies (Fig. 7). The main advantage is that biomasses with a high nitrogen content could be used without diluting the SNG product too much with $\mathrm{N}_{2}$ because organic nitrogen is mineralized to $\mathrm{NH}_{3} / \mathrm{NH}_{4}{ }^{+}$in the biogas reactor [26]. The $\mathrm{NH}_{3} / \mathrm{NH}_{4}{ }^{+}$produced in the digester would then follow the water, which means that most of it would be removed in the mechanical water removal (e.g. centrifuge). The $\mathrm{NH}_{3} / \mathrm{NH}_{4}{ }^{+}$that would end up in the SOEC or gasifier would be converted to $\mathrm{N}_{2}$ and end up in the SNG product. If this novel system is combined with an anaerobic digester it would make sense to optimize the digester for nitrogen mineralization and not for biomass conversion, since residual biomass in the digestate is converted in the gasifier. Another advantage of the integration is that more waste heat is available from the methane synthesis, which means that the system would be able to handle higher water and ash contents in the biomass - this means that the centrifuge could have an output with a water content of $75-80 \mathrm{wt} \%$ and therefore have a lower electricity consumption than if a water content of $70 \mathrm{wt} \%$ was required. Considering the biomass listed in Table 1, it would be necessary to combine the novel system with an anaerobic digester for mineralization of nitrogen in the case of sewage sludge ${ }^{3}$.

The advantages of integrating the system with an anaerobic digester would therefore be that the system could handle biomasses with higher $\mathrm{N}$, water and ash contents. These advantages could also be achieved by supplying the novel system with an external carbon source, which simply could be a $\mathrm{CO}_{2}$ feed (Fig. 8). Nitrogen would of course not be mineralized in such a system, so the benefits in terms of nitrogen, would come by diluting the nitrogen in the SNG with methane originating from the external carbon source. Instead of supplying an external carbon source in the form of a gas, it could be in the form of a solid with a low nitrogen content, such as wood. The wood could then either be mixed with the high $\mathrm{N}$ biomass before the steam dryer, or be dried in a dedicated wood steam dryer and then mixed with the high $\mathrm{N}$ biomass before the gasifier.

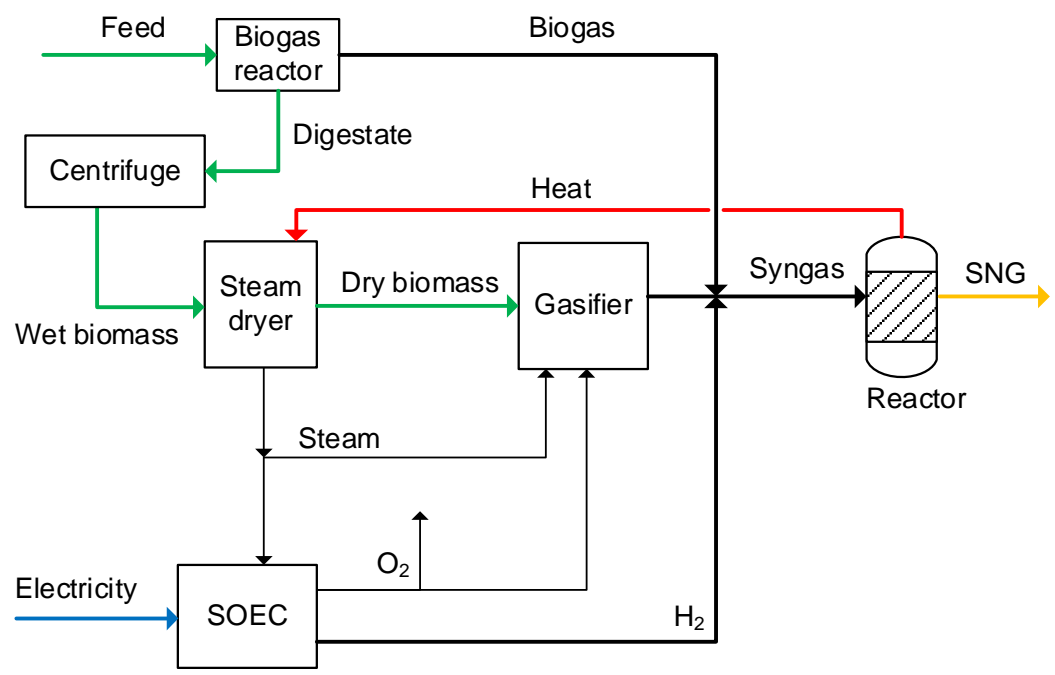

Fig. 7. Simplified flowsheet of the combination of an anaerobic digester (biogas reactor) with the novel system. Color description: green = biomass, blue = electricity, yellow $=$ biofuel, red $=$ heat.

\footnotetext{
${ }^{3} \mathrm{Pig}$ manure also has a high nitrogen content, but because the value of $4.40 \mathrm{wt} \%$ (Table 1 ) is at a water content of $92.1 \mathrm{wt} \%$, it is expected that $\mathrm{NH}_{3} / \mathrm{NH}_{4}{ }^{+}$is included in the value. In addition, digested pig manure has a nitrogen content of 2.45 wt\% (Table 1), which would be sufficiently low for the novel system.
} 


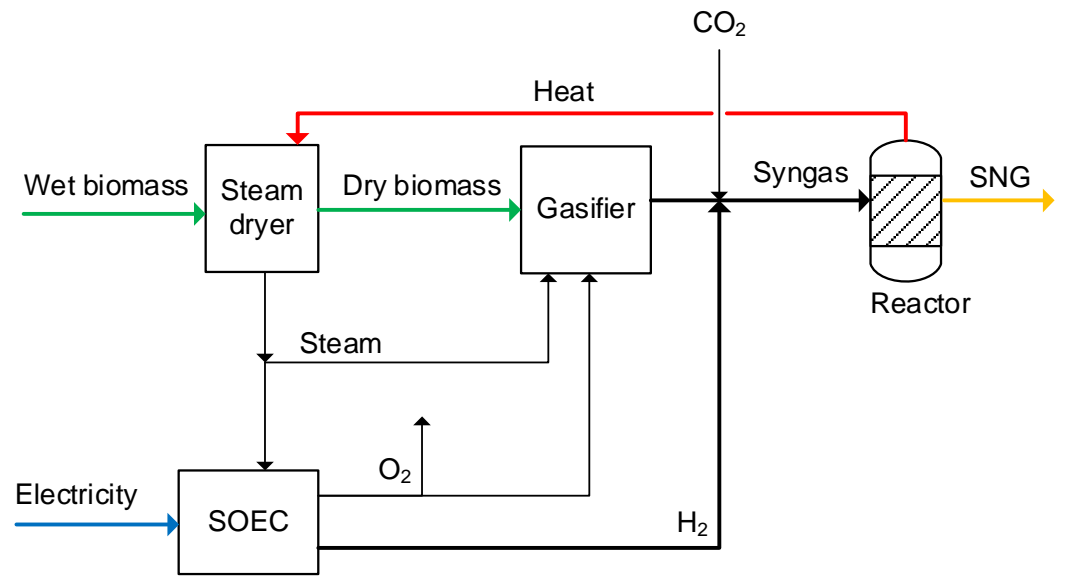

Fig. 8. Simplified flowsheet of the combination of an external $\mathrm{CO}_{2}$ feed with the novel system. Color description: green $=$ biomass, blue = electricity, yellow $=$ biofuel, red $=$ heat.

\section{Conclusion}

A novel system concept for the energy efficient thermochemical conversion of very wet biomasses has been proposed. The system integrates steam drying, solid oxide electrolysis cells (SOEC) and gasification for the production of synthetic natural gas (SNG). The analysis shows that the system can handle biomasses with $82-84 \%$ more water than a "conventional" system, which in other words means that if a mechanically dried biomass with a water content of $70 \mathrm{wt} \%$ is supplied, then the novel system can tolerate an ash content of $50 \mathrm{wt} \%$ (dry basis), while the conventional system would be able to tolerate $10 \mathrm{wt} \%$ ash. A high tolerable ash content is an advantage because very wet biomasses, such as sewage sludge and manure, have a high ash content. Sewage sludge typically also has a high nitrogen content, which is a problem in the production of SNG because the nitrogen ends up in the SNG product. An effective way of reducing this problem is by combining the novel system with an anaerobic digester for the mineralization of nitrogen. A more primitive solution is to dilute the nitrogen by adding a low nitrogen carbon source, such as $\mathrm{CO}_{2}$ or wood. The analysis also shows that the total efficiency of the system is $69-70 \%$ depending on the biomass ash content (1-50 wt\%), and because electricity is used for the conversion of steam to hydrogen, almost all the carbon in the biomass ends up in the SNG product, resulting in a biomass to SNG energy ratio of $165 \%$.

\section{References}

[1] Mignard D, Pritchard C. On the use of electrolytic hydrogen from variable renewable energies for the enhanced conversion of biomass to fuels. Chem Eng Res Des 2008;86:473-87.

[2] Bernical Q, Joulia X, Noirot-Le Borgne I, Floquet P, Baurens P, Boissonnet G. Sustainability Assessment of an Integrated High Temperature Steam Electrolysis-Enhanced Biomass to Liquid Fuel Process. Ind Eng Chem Res 2013;52:7189-95.

[3] Gassner M, Maréchal F. Thermo-economic optimisation of the integration of electrolysis in synthetic natural gas production from wood. Energy 2008;33:189-98.

[4] Clausen LR. Maximizing biofuel production in a thermochemical biorefinery by adding electrolytic hydrogen and by integrating torrefaction with entrained flow gasification. Energy 2015;85:94104.

[5] Clausen LR, Houbak N, Elmegaard B. Technoeconomic analysis of a methanol plant based on gasification of biomass and electrolysis of water. Energy 2010;35:2338-47.

[6] Specht M, Bandi A, Baumgart F, Muray CM, Gretz J. Synthesis of methanol from biomass/CO2 resources. Greenh Gas Technol 1999:723-7.

[7] Ouellette N, Rogner $\mathrm{H}-\mathrm{H}$, Scott DS. Hydrogen from remote excess hydroelectricity. Part II: 
Hydrogen peroxide or biomethanol. Int J Hydrogen Energy 1995;20:873-80.

[8] Pozzo M, Lanzini A, Santarelli M. Enhanced biomass-to-liquid (BTL) conversion process through high temperature co-electrolysis in a solid oxide electrolysis cell (SOEC). Fuel 2015;145:39-49.

[9] Gil-Lalaguna N, Sánchez JL, Murillo MB, Atienza-Martínez M, Gea G. Energetic assessment of airsteam gasification of sewage sludge and of the integration of sewage sludge pyrolysis and airsteam gasification of char. Energy 2014;76:652-62.

[10] Wang Z, Chen D, Song X, Zhao L. Study on the combined sewage sludge pyrolysis and gasification process: mass and energy balance. Environ Technol 2012;33:1-8.

[11] Ud Din Z, Zainal ZA. Biomass integrated gasification-SOFC systems: Technology overview. Renew Sustain Energy Rev 2016;53:1356-76.

[12] Svoboda K, Martinec J, Pohořelý M, Baxter D. Integration of biomass drying with combustion/gasification technologies and minimization of emissions of organic compounds. Chem Pap 2009;63.

[13] Sentry air systems. Activated Carbon Adsorption Ratings. http://www.sentryair.com/activatedcarbon-filter.htm (accessed May 1, 2016).

[14] Elmegaard B, Houbak N. DNA - a general energy system simulation tool. SIMS 2005, 46th conference on simulation and modeling, Trondheim, Norway: 2005, p. 43-52.

[15] Tech. Univ. Denmark - Mech. Eng. Dep. Homepage of the thermodynamic simulation tool DNA. http://orbit.dtu.dk/query?record=231251 (accessed September 28, 2016).

[16] Energy research Centre of the Netherlands. Phyllis2, database for biomass and waste. https://www.ecn.nl/phyllis2 (accessed May 1, 2016).

[17] Ahrenfeldt J, Henriksen U, Jensen TK, Gøbel B, Wiese L, Kather A, et al. Validation of a continuous combined heat and power (CHP) operation of a two-stage biomass gasifier. Energy and Fuels 2006;20:2672-80.

[18] Bentzen J, Hummelsh $\varnothing j$ R, Henriksen U. Upscale of the two-stage gasification process. Proc 2 World Conf Technol Exhib Biomass Energy Ind 2004;10-14 May,:1004-7.

[19] Clausen LR, Elmegaard B, Ahrenfeldt J, Henriksen U. Thermodynamic analysis of small-scale dimethyl ether (DME) and methanol plants based on the efficient two-stage gasifier. Energy 2011;36:5805-14.

[20] Sunfire. Sunfire supplies Boeing with world's largest commercial reversible electrolysis (RSOC) system. Press Release 2016. http://www.sunfire.de/en/company/press/detail/sunfire-suppliesboeing-with-worlds-largest-commercial-reversible-electrolysis-rsoc-system-16 (accessed January 3, 2017).

[21] Hauch A, Brodersen K, Chen M, Mogensen MB. Ni/YSZ electrodes structures optimized for increased electrolysis performance and durability. Solid State lonics 2016;293:27-36.

[22] Hansen JB. Solid oxide electrolysis - a key enabling technology for sustainable energy scenarios. Faraday Discuss 2015;182:9-48.

[23] Mathiesen B V, Ridjan I, Connolly D, Nielsen MP, Hendriksen P V, Mogensen MB, et al. Technology Data for High Temperature Solid Oxide Electrolyser Cells, Alkali and Pem Electrolysers 2013:1-16.

[24] Duret A, Friedli C, Maréchal F. Process design of Synthetic Natural Gas (SNG) production using wood gasification. J Clean Prod 2005;13:1434-46.

[25] Jensen J., Poulsen J., Andersen N. From Coal To Clean Energy. Nitrogen+Syngas 2011:1-5.

[26] Parkin GF, Owen WF. Fundamentals of Anaerobic Digestion of Wastewater Sludges. J Environ Eng 1986;112:867-920.

[27] The Danish Gas Legislation. Bekendtg $\varnothing$ relse om gasreglementets afsnit C-12, bestemmelser om gaskvaliteter (in danish). https://www.retsinformation.dk/Forms/R0710.aspx?id=144715 (accessed May 1, 2016). 
[28] Bejan A, Tsatsaronis G, Moran M. Thermal Design and Optimization. Wiley; 1996. 


\section{Appendix}

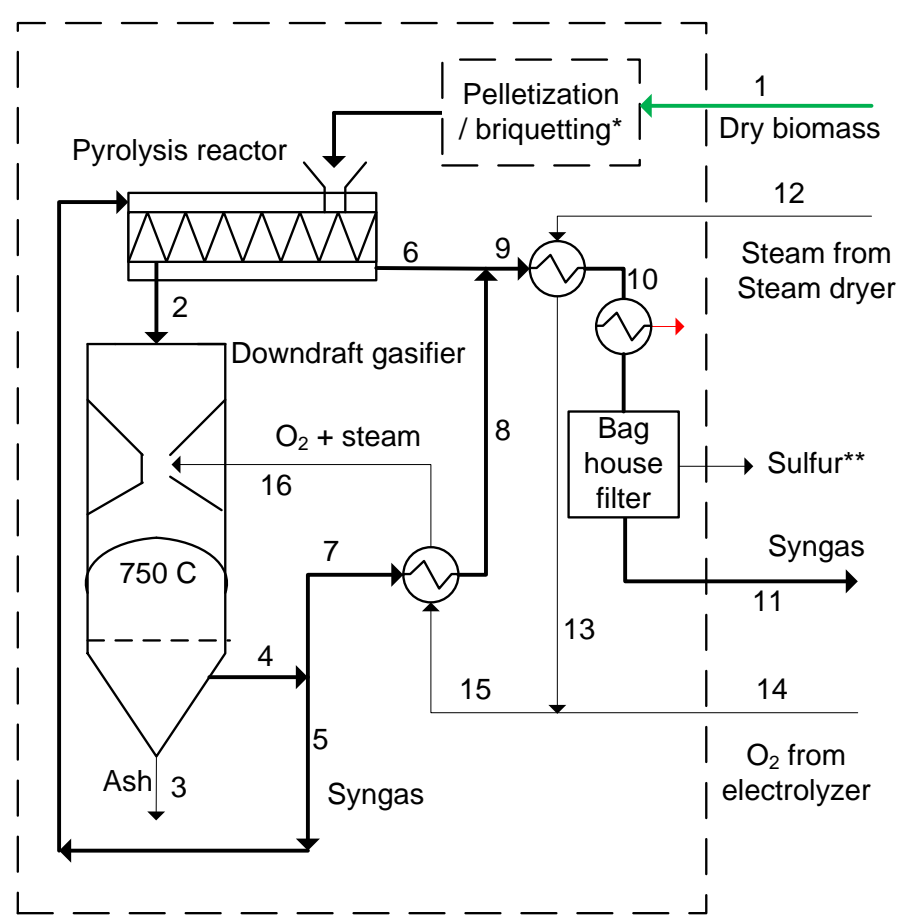

Two-stage gasifier block

\begin{tabular}{r|rrrrr} 
& $\mathrm{t}(\mathrm{C})$ & $\mathrm{p}(\mathrm{bar})$ & $\mathrm{m}(\mathrm{kg} / \mathrm{s})$ & $\mathrm{h}(\mathrm{kJ} / \mathrm{kg}) \mathrm{s}\left(\mathrm{kJ} /\left(\mathrm{kg}^{*} \mathrm{~K}\right)\right)$ \\
\hline 1 & 110 & 0.97 & 0.571 & -8602 & 1.278 \\
2 & 630 & 0.97 & 0.571 & -7604 & - \\
3 & 730 & 0.94 & 0.258 & -11615 & 1.213 \\
4 & 730 & 0.94 & 0.571 & -7151 & 12.567 \\
5 & 730 & 0.94 & 0.549 & -7151 & 12.567 \\
6 & 210 & 0.94 & 0.549 & -8189 & 11.120 \\
7 & 730 & 0.94 & 0.022 & -7151 & 12.567 \\
8 & 217 & 0.94 & 0.022 & -8176 & 11.145 \\
9 & 210 & 0.94 & 0.571 & -8188 & 11.121 \\
10 & 184 & 0.94 & 0.571 & -8237 & 11.017 \\
11 & 90 & 0.94 & 0.567 & -8453 & 10.615 \\
12 & 110 & 0.97 & 0.200 & -13274 & 10.946 \\
13 & 180 & 0.97 & 0.200 & -13134 & 11.282 \\
14 & 249 & 0.97 & 0.058 & 212 & 6.948 \\
15 & 187 & 0.97 & 0.258 & -10118 & 10.470 \\
16 & 237 & 0.97 & 0.258 & -10031 & 10.650
\end{tabular}

Fig. 9. Detailed flowsheet of the Two-stage gasifier block shown in Fig. 6. *Pelletization or briquetting will probably be needed for biomasses other than wood chips. ${ }^{* *}$ Most of the sulfur is expected to be captured with the particles in the bag house filter. A sulfur guard is needed before the catalytic synthesis reactor. Color description: green = biomass, red $=$ heat. 


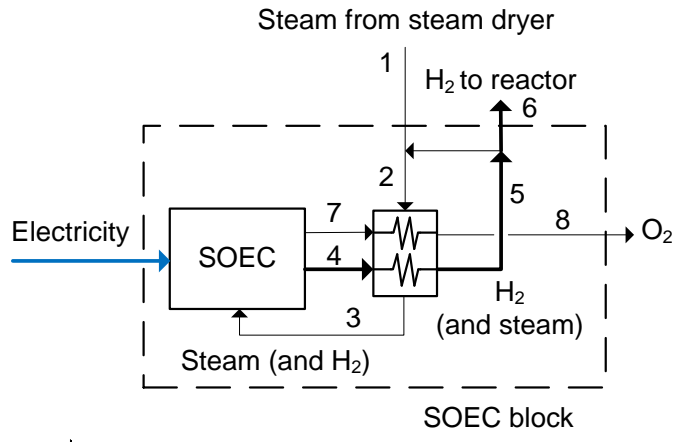

\begin{tabular}{r|rrrrr} 
& $\mathrm{t}(\mathrm{C})$ & $\mathrm{p}($ bar $)$ & $\mathrm{m}(\mathrm{kg} / \mathrm{s})$ & $\mathrm{h}(\mathrm{kJ} / \mathrm{kg}) \mathrm{s}\left(\mathrm{kJ} /\left(\mathrm{kg} \mathrm{K}^{\star}\right)\right)$ \\
\hline 1 & 110 & 0.97 & 0.532 & -13274 & 10.946 \\
2 & 126 & 0.97 & 0.554 & -13053 & 11.921 \\
3 & 770 & 0.97 & 0.554 & -11600 & 14.057 \\
4 & 800 & 0.97 & 0.176 & -4645 & 35.706 \\
5 & 249 & 0.97 & 0.176 & -7978 & 31.366 \\
6 & 249 & 0.97 & 0.154 & -7978 & 31.366 \\
7 & 800 & 0.97 & 0.378 & 789 & 7.697 \\
8 & 249 & 0.97 & 0.378 & 212 & 6.948
\end{tabular}

Fig. 10. Detailed flowsheet of the SOEC block shown in Fig. 6. Color description: blue = electricity.

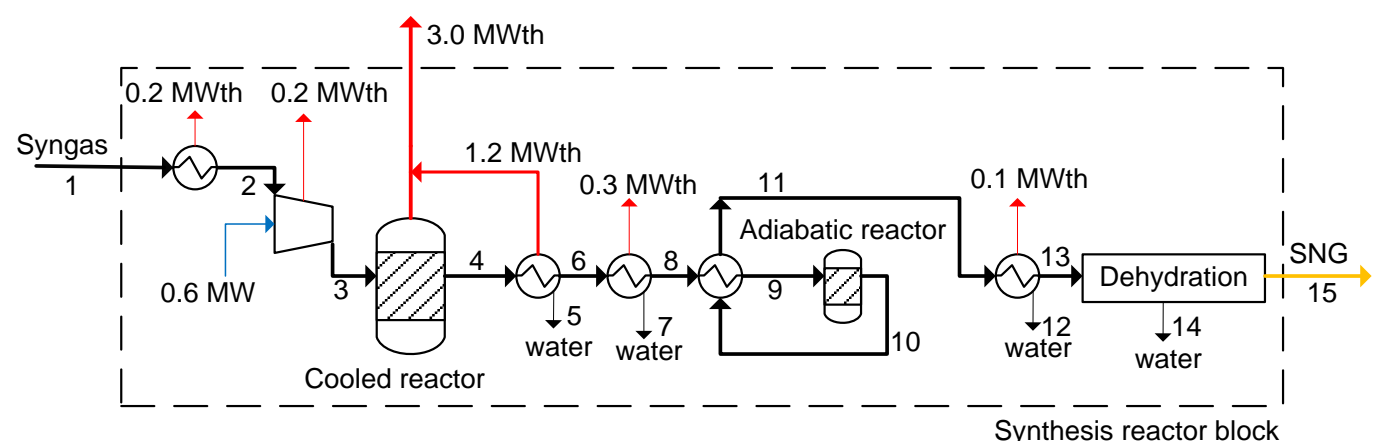

\begin{tabular}{r|rrrrrrrrrrrrr} 
& $\mathrm{t}(\mathrm{C})$ & $\mathrm{p}(\mathrm{bar})$ & $\mathrm{m}(\mathrm{kg} / \mathrm{s})$ & $\mathrm{h}(\mathrm{kJ} / \mathrm{kg}) \mathrm{s}\left(\mathrm{kJ} /\left(\mathrm{kg}{ }^{\star} \mathrm{K}\right)\right)$ & & $\mathrm{t}(\mathrm{C})$ & $\mathrm{p}(\mathrm{bar})$ & $\mathrm{m}(\mathrm{kg} / \mathrm{s})$ & $\mathrm{h}(\mathrm{kJ} / \mathrm{kg}) \mathrm{s}\left(\mathrm{kJ} /\left(\mathrm{kg}^{*} \mathrm{~K}\right)\right)$ \\
\hline 1 & 164 & 0.94 & 0.721 & -8352 & 15.212 & & 9 & 220 & 7.00 & 0.187 & -4348 & 12.166 \\
2 & 70 & 0.94 & 0.721 & -8601 & 14.570 & 10 & 308 & 7.00 & 0.187 & -4348 & 12.293 \\
3 & 236 & 7.00 & 0.721 & -8157 & 14.215 & 11 & 143 & 7.00 & 0.187 & -4803 & 11.377 \\
4 & 300 & 7.00 & 0.721 & -10622 & 11.573 & 12 & 40 & 7.00 & 0.010 & -15803 & 4.088 \\
5 & 125 & 7.00 & 0.431 & -15446 & 5.097 & 13 & 40 & 7.00 & 0.177 & -4572 & 10.683 \\
6 & 125 & 7.00 & 0.290 & -7683 & 11.377 & 14 & 40 & 7.00 & 0.002 & -13395 & 9.675 \\
7 & 40 & 7.00 & 0.104 & -15803 & 4.088 & 15 & 40 & 7.00 & 0.175 & -4468 & 10.664 \\
8 & 40 & 7.00 & 0.187 & -4803 & 11.027 & & & & & &
\end{tabular}

Fig. 11. Detailed flowsheet of the synthesis reactor block shown in Fig. 6. Color description: blue = electricity, yellow = biofuel, red $=$ heat . 